\title{
The Seamless Relationship between Teaching Poetry and Language Learning
}

\author{
Çağrı Tuğrul Mart
}

Department of English Language Teaching, Ishik University, Erbil, Iraq

Received November 26, 2020; Revised January 5, 2021; Accepted February 3, 2021

\section{Cite This Paper in the following Citation Styles}

(a): [1] Çağrı Tuğrul Mart, "The Seamless Relationship between Teaching Poetry and Language Learning," Universal Journal of Educational Research, Vol. 9, No. 2, pp. 288 - 291, 2021. DOI: 10.13189/ujer.2021.090204.

(b): Çăgrt Tuğrul Mart (2021). The Seamless Relationship between Teaching Poetry and Language Learning. Universal Journal of Educational Research, 9(2), 288 - 291. DOI: 10.13189/ujer.2021.090204.

Copyright $(2021$ by authors, all rights reserved. Authors agree that this article remains permanently open access under the terms of the Creative Commons Attribution License 4.0 International License

\begin{abstract}
The hesitation to use poetry in the language classroom comes from its deemed inappropriateness in language learning. The use of non-standard vocabulary and broken syntax and grammar rules begets ambivalence toward poetry. In addition, language learners cannot overcome this vacillation due to poetry's demands on imaginative engagement. However, poetry is a content-rich reading tool which makes it an ideal, and authentic context to improve vocabulary and grammar acquisition, enhance written expression and oral discussion. The inclusion of poetry in language teaching serves as a catalyst for improvement of pronunciation, stress and rhythm. The core premise of studying poetry is its merit to spawn engagement of learners to construct meaningful interpretations and build knowledge through the identification of linguistic elements. Poetry should be embraced for its mightiness to expose learners to a great wealth of comprehensible input. Penetrating into poetry and experimenting with its creatively used style of language to infer meaning is an optimal grounding to decipher language patterns and weld this knowledge into oral production. This article supports the inclusion of poetry in language learning for creating conditions conducive to language enrichment and proposes that poetry be used at all levels of instruction to enable learners to make huge leaps in language learning.
\end{abstract}

Keywords Poetry, Language Learning, Meaningful Input, Oral Communication

\section{Introduction}

Owing to its reputation as esoteric, elite, or effete [1], the teaching of poetry has remained impotent in language classes. Learners' resistance to poetry perpetuates the belief that the study of poetry is "dull and pointless" [2] (p.7). Language teachers prefer delaying the introduction of poetry for beginning and intermediate learners as it is often associated with a perilous experience ascribed to it due to its difficulty. Poetry is reserved to advanced level language programs on the grounds of its arcane language and labyrinthical structure. Nevertheless, poetry which is defined by Coleridge [3] as "the best words in the best order" is a central pedagogical feature of language teaching in its own right and should be placed at the heart of language classes to reclaim the creative [4]. Current thinking in language learning and teaching has claimed univocal position of poetry in the language classroom by laying stress on its prominence to make huge leaps in language learning. The inclusion of poetry in language teaching provides occasion at all levels for the development of language knowledge. Poetry is semantically loaded language resource and calls for imaginative and affective engagement of learners. Exposure to intense lessons in vocabulary and grammar by virtue of poetry can be used as a springboard for language acquisition process [5]. Hadaway, Vardell, and Young [6] construct a convincing argument for the study of poetry in the language curriculum and point out that poetry acts as a subsidiary to the act of oral language. Comeaux [7] appreciates poetry incorporated into the language curriculum about its appropriateness for the 
integration of language skills. Elster [8] touches on the value of poetry for the development of critical thinking skills, imagination, and interpretation. Kramsch and Mueller [9] accentuate the benefits of using poetry in language teaching for perfecting pronunciation and intonation of learners because language learners develop their ear for the new language by bringing sound structures and the rhythms into their focus. Bates [10] confidently argues that poetry embodies intensive use of language and without any hesitation makes language learning more creative. Poems are authentic models for the norms of language use and they appeal to the language learners' imagination and emotions; hence provide stimuli for oral discussion as a result of interaction with texts [11]. The potential of poems serves as a catalyst for language improvement through involving "learners in thinking, feeling and interacting in ways which are conducive to language acquisition" [12] (p.41). The seamless relationship between teaching poetry and language acquisition is the central concern of this paper.

\section{Literature Review}

Although downgraded as it was thought to be inaccessible for language learners, literature has made a place for itself in language teaching and has prevailed as a contributing force in language instruction since the late 1970s $[13,14]$. It has been deemed necessary to take heed of literature instruction for its well-known cachet as a viable approach in the acquisition of advanced language competence [15, 16, 17]. The core premise of using literature is that it provides clear advantages for learners to perceive the characteristics of target structures in contexts and use these forms for communicative language use $[17,18,19]$. Literature is an input-rich source for coming to good terms with knowledge of language structures, reading proficiency, enriched vocabulary, improving skills in the target language, thinking skills, and cultural awareness [20]. Poetry, a form of literature, is an important component of language curriculum and has the potential to endorse learners to become cognizant of language features and their meaningful use in context.

Maley [21] presents some certain reasons for incorporating poetry into language curriculum owing to its unique characteristics as memorability, rhythmicality, recitability, ambiguity, non-triviality, universality, playfulness, reactional, motivation and interaction. Memorability includes holding fragments or the whole poem in mind; rhythmicality refers to repeated sound and stress patterns that occur in regular sequences and provides a basis for active participation in the construction of meaning in classroom discussions; recitability offers a ready-made opportunity to read aloud. The recitation of poetry helps learners eradicate negative feelings about it and indorse them for self-confidence; ambiguity is connected to creating situations in the language classroom for the transferal of concepts of cultural value and language backgrounds; non-triviality highlights the value of poetry for exposing learners to a great wealth of input. It goes without saying that comprehensible input is a sine qua non condition for efficient intake; universality describes an extensive range of enrichment in themes common to all cultures and their perusal in discussions leads to desired outcomes in the development of communication skills; playfulness is all about experimenting with the language to test its elasticity; reactional language is situating the poetry reading task within the contexts of group discussions to encourage learners to react interpretations of other learners; and motivation, an important aspect of language learning, is concerned with maintaining positive attitudes of learners towards poetry since poetry is concerned at large beyond the language skills of most learners. The relevance of the poem to the learners, the linguistic features of the poem and the role of the teacher can offset the difficulty. An approach to the task of reading poetry involving discussions to consciously and actively construct meaning of the poem can inevitably lead to comprehension. Finally, interaction involves the discussion of poetry, which is an authentic context, to communicate effectively.

Krashen's 'Input Hypothesis' [22, 23] situates comprehensible input at the core of language acquisition. When a poem is studied, it is crucial that learners must understand messages for meaning construction. Insufficient exposure to the meaningful use of the target language leaves little room for language acquisition. Poetry should be espoused for its well-recognized value as input to attain advanced-level language abilities. The virtue of poetry lies in its mightiness to weave form and meaning in an authentic task [24]. Attending to poetry raises awareness of form-meaning connections and encourages language learners for accurate and fluent use of target language. Poetry is being perceived distinguished by the American poet, Dana Gioia who asserts that "poetry is the art of using words charged with the utmost meaning" [25] (p. 20). Poetry is the use of ordinary language in extraordinary ways [26] as poets experiment with language in different ways than it is used in everyday contexts. Maley goes on to say that creation of new metaphors, transformation of the syntax in unconventional ways, extension of the semantic range of words and creation of new collocations is what makes poetry a worthy source in language classrooms. The use of poetry is an important part of instruction in language education because "poetry gives teachers an authentic text in which to work on phonics, phonemic awareness, and language development skills such as rhyme, word families, and alliteration" [27] (p. 32). Cumming [28] for instance, supports the use of poetry in elementary classrooms to offer young learners a medium for joyful learning. A high level of persuasive support to include poetry in secondary 
school English curriculum comes from Peskin [29] who argues that poetry builds an ethos of engagement in meaningful and active thinking. In the same vein, Newfield and D'abdon [30] in their study found that the study of poetry in secondary education is a useful context to acquire language competence.

The rewards of teaching poetry in the language classroom are countless. The experience of studying poetry is pedagogically significant because poems are laden with a concentrated form of language; hence serve as a model to bring learners into discerning the new uses of language. One of the major values for persisting in teaching poetry is its merit to focus on formal features to negotiate meaning. When reading poetry, learners draw their attention to the function of formal features and accrue quite tangible benefits to develop language awareness. Experimenting with the language by means of reading poetry serves as the basis for coming to good terms with linguistic features. There is no blinking the fact that poetry is a potentially worthwhile source of comprehensible input to evoke robust efficiency in language development. Schultz [5] underscores the need for the inclusion of poetry in language curriculum to enable learners to improve their pronunciation and intonation. Kramsch and Mueller [9] address the contact between teaching poetry and pronunciation development and argue that rhythms and sound structures of poetry help learners develop their ear for the new language. Schultz [5] goes on to say that the wider use of poetry can be profitable for drawing attention of learners to grammatical and lexical structures. Moreover, the wisdom of teaching poetry to expand language competence lies in the fact that learners practice decoding the language and understand the concepts which could result in high level of critical reading skills. Literary texts are "illustrations of the grammatical rules" [31] (p.3); therefore, samples of good writings in poetry serve as the basis for creative language use and enable learners to acquire language structures. This indicates that poetry-oriented language classes make room for refining creative abilities for writing; thus, are compatible with language proficiency.

The wisdom of poetry reading lies in its power for extending language use and inspires learners to adapt linguistics to classroom discussions. Any form of literature be it drama, story, novel or poetry is an excellent means for the development of oral communication. In attempting to support his argument for the introduction of literary texts in the language classroom, Widdowson [32] points out that literature should be embraced in language teaching "not to provide information about particular pieces of literature in the syllabus but to get the learners to recognize how these particular pieces exemplify more general principles of communication" (p. 84). The appropriateness of poetry as a motivating medium to denote the awareness of language endows learners to practice with language for extending language usage and construct fluency. The central feature of poetry reading is its emphasis on stimulating learners to arrive at meaningful interpretations through striving to discover linguistic elements and creating classroom discourse community. There is no blinking the fact that the study of poetry culminates in practicing with meaningful content, decoding the language and understanding the concepts which display significant advantages for increased output. Learners expand their language repertoire through discovering new concepts and embrace possibilities poetry offers for meaningful interaction. The embrace of beautifully crafted words and furnished language in poetry can serve as a springboard to express meaning and act as a stimulus to spark production of meaningful discourse. Discourse-based language instruction through inclusion of poetry offers learners an avenue to create meaning and argue for their interpretations, integrate new knowledge into old, weave skills they need for mastery of language and become engrossed in dialogic talk.

\section{Conclusions}

Poetry can offer an acquisition-rich environment for language learners for that reason it should form a valuable part of the language curriculum. Teaching poetry engages learners in progress of language awareness and provides an avenue for coming to good terms with written and communicative competence. The instructional potential of poetry can be an important initiative for learners to notice linguistic features and engage in knowledge building, construct meaning and articulate their interpretations which will help them promote their language output.

\section{REFERENCES}

[1] Cranston, M, "Rhyme or Reason? The Teaching of Poetry in the Foreign Language Classroom," The French Review, vol. 76, no. 5, pp. 954-966, 2003.

[2] Ofsted, "Poetry in Schools: A Survey of Practice, 2006/07," London: Ofsted, 2007.

[3] Coleridge, S.T, “Table Talk I in Collected Works," London: Routledge, 1990. (Original work published 1827)

[4] Elting, S., Firkins, A, "Dramatizing Poetry in the Second Language Classroom," English Teaching: Practice and Critique, vol. 5, no. 3, pp. 127-136, 2006.

[5] Schultz, J, "The Uses of Poetry in the Foreign Language Curriculum," The French Review, vol. 69, no. 6, pp. 920-932, 1996.

[6] Hadaway, N. L., Vardell, S. M., Young, T. A, "Scaffolding Oral Language Development through Poetry for Students Learning Language," The Reading Teacher, vol. 54, no. 8, pp. 796-806, 2001. 
[7] Comeaux, P, "Performing Poetry: Centering the Language Arts Programme," Contemporary Education, vol. 65, no. 2, pp. 77-81, 1994.

[8] Elster, C, "Entering and Opening the World of a Poem," Language Arts, vol. 78, no. 1, pp. 71-77, 2000.

[9] Kramsch, C., Mueller, M, "Celebrating, Understanding, Celebrating Poetry in the Foreign Language Class," Lincolnwood, Illinois: National Textbook Company, 1991.

[10] Bates, M, “A Poet's View: From Hats to Socks," IATEFL Issues, vol. 157, no. 13, 2000.

[11] Tomlinson, B, "Language through literature and literature through language,” EFL Gazette: March, 9, 1985.

[12] Tomlinson, B, "Using Poetry with Mixed Ability Classes," ELT Journal, vol, 40, no. 1, pp. 33-41, 1986.

[13] Paesani, K, "Research in Language-Literature Instruction: Meeting the Call for Change?" Annual review of Applied Linguistics, vol. 31, pp. 161-181, 2011.

[14] Mart, Ç.T, "The Contentious Debate Over the Language Literature Division," Journal of Language and Cultural Education, vol. 6, no. 1, pp. 117-127, 2018. DOI: 10.2478/jolace-2018-0008

[15] Paran, A, "The Role of Literature in Instructed Foreign Language Learning and Teaching: An Evidence-Based Survey" Language Teaching, vol. 41, no. 4, pp. 465-496, 2008. DOI: $10.1017 / \mathrm{S} 026144480800520 \mathrm{X}$

[16] Weber-Feve, S, "Integrating Language and Literature: Teaching Textual Analysis with Input and Output Activities and an Input-To-Output Approach," Foreign Language Annals, vol. 42, no.3, pp. 435-467, 2009. DOI: 10.1111/j.1944-9720.2009.01035.x

[17] Mart, Ç.T, "Literature in the Language Classroom: A Recipe to Maximize Learning," L1 Educational Studies in Language and Literature, vol. 18, pp. 1-25, 2018. DOI: 10.17239/L1ESLL-2018.18.01.09

[18] Lazar, G, "Literature and Language Teaching," Cambridge: UK: Cambridge University Press, 1993.

[19] Mart, Ç.T, "Reader-response theory and literature discussions: A springboard for exploring literary texts" The New Educational Review, vol. 56, no. 2, pp. 78-87, 2019. DOI: 10.15804/tner.2019.56.2.06
[20] Mart, C.T, "A Comparison of Form-Focused, Content-Based and Mixed Approaches to Literature-Based Instruction to Develop Learners' Speaking Skills," Cogent Education, vol. 6, pp. 1-27, 2019. DOI: 10.1080/2331186X.2019.1660526

[21] Maley A, "Poetry and Song as Effective Language-Learning Activities," In Wilga M. Rivers, Interactive Language Teaching (pp. 93-108). New York: Cambridge University Press, 1990

[22] Krashen, S, "Second Language Acquisition and Second Language Learning," Oxford: Pergamon Press, 1981.

[23] Krashen, S, "Principles and Practice in Second Language Acquisition," Oxford: Pergamon Press, 1982.

[24] Hanauer, D, "Poetry Reading in the Second Language Classroom," Language Awareness, vol. 6, no. 1, pp. 2-16, 1997.

[25] Gioia, D, "Can Poetry Matter? Essays on Poetry and American Culture," Saint Paul, Graywolf Press, 1998.

[26] Maley, A, “That's for Your Poetry Book!” In R. Carter \& J. McRae (Eds.), Language, Literature and the Learner: Creative Classroom Practice (pp. 100-114). London: Longman, 1996.

[27] Stickling, S., Prasun, M., Olsen, C. "Poetry: What's the Sense in Teaching It?" Illinois Reading Council Journal, vol. 39 no. 3, pp. 31-40, 2011.

[28] Cumming, R, "Language play in the classroom: encouraging children's intuitive creativity with words through poetry," Literacy, vol. 41, no. 2, pp. 93-101, 2007. DOI: 10.1111/j.1467-9345.2007.00463.x

[29] Peskin, J, "The Genre of Poetry: Secondary School Students' Conventional Expect at Ions and Interpretive Operations," English in Education, vol. 41, no. 3, pp. 20-36, 2007. DOI: 10.1111/j.1754-8845.2007.tb01162.x

[30] Newfield, D., D'abdon, R, "Reconceptualising Poetry as a Multimodal Genre," TESOL Quarterly, vol. 49, no. 3, pp. 510-532, 2015. DOI:10.1002/tesq.239

[31] Duff, A., Maley, A, "Literature,” Oxford: Oxford University Press, 1990.

[32] Widdowson, H. G, "Stylistics and the Teaching of Literature," London: Longman, 1975. 